\title{
Nutrient release by a Brazilian sedimentary zeolite
}

\author{
MARISA B.M. MONTE ${ }^{1}$, ANTONIETA MIDDEA ${ }^{1}$, PAULO R.P. PAIVA ${ }^{1}$, ALBERTO C.C. BERNARDi ${ }^{2}$, \\ NÉLIO G.A.M. REZENDE ${ }^{3}$, MILTON BAPTISTA-FILHO ${ }^{4}$, MARCELO G. SILVA ${ }^{4}$, \\ HELION VARGAS ${ }^{4}$, HELIO S. AMORIM ${ }^{5}$ and FERNANDO DE SOUZA-BARROS ${ }^{5}$ \\ ${ }^{1}$ Serviço de Desenvolvimento de Novos Produtos Minerais, Centro de Tecnologia Mineral, CETEM \\ Av. Ipê, 900, Ilha do Fundão, Cidade Universitária, 21941-590 Rio de Janeiro, RJ, Brasil \\ ${ }^{2}$ Empresa Pecuária Sudeste, Rodovia Washington Luiz, km 234, Fazenda Canchim \\ Caixa Postal 339, 13560-970 São Carlos, SP, Brasil \\ ${ }^{3}$ Companhia de Pesquisas e Recursos Minerais (CPRM), Superintendência de Recursos Minerais \\ Av. Dr. Freitas, 3645, Bairro do Marco, 66095-110 Belém, PA, Brasil \\ ${ }^{4}$ Laboratório de Ciências Físicas, Universidade do Estado do Norte Fluminense, UENF \\ Av. Alberto Lamego, 2000, Parque Califórnia, 28013-602 Campos dos Goytacazes, RJ, Brasil \\ ${ }^{5}$ Instituto de Física, Universidade Federal do Rio de Janeiro, Caixa Postal 68528, 21941-972 Rio de Janeiro, RJ, Brasil
}

Manuscript received on June 4, 2008; accepted for publication on March 5, 2009; contributed by FERNANDO DE SOUZA BARROS*

\begin{abstract}
This report describes the characterization of a sedimentary occurrence from the Parnaíba Basin, Brazil, containing the zeolite stilbite intertwined with smectitic clay mineral. The head samples from different sites present a wide content range of the zeolitic phase $-15 \%$ to $50 \%$. The use of simple separation techniques - conventional gravitic treatments yields concentrates containing about $67 \%$ of the zeolitic component. Assays with the amendments of these concentrates with plant nutrients yield release rates matching those reported for similar commercial products.
\end{abstract}

Key words: sedimentary zeolite, Parnaíba Basin, plant nutrients, nutrient attachment and release.

\section{INTRODUCTION}

The concept of soil amelioration involves the application of amendments to modify adverse properties, such as sandy soils with low water and nutrient retention capacity. Soil conditioners, however, have a wide composition ranging from organic to inorganic nature, and even synthetic origins (Stewart 1975). Thus the selection of these amendments and their appropriate forms of applications require controlled field tests to each specific crop and regional climatic conditions.

The use of minerals for agricultural purposes is becoming widespread (van Straaten 2006), and zeolitic concentrates have a special niche in this category. The

\footnotetext{
*Member Academia Brasileira de Ciências Correspondence to: F. de Souza Barros E-mail: fsbarros@if.ufrj.br
}

worldwide number of identified natural zeolitic concentrates - about forty - and of synthesized ones - over one hundred and fifty - demonstrate both their great variety and the present-day interest on their potential applications in the industry and the agriculture (Vaughan 1978, Gasparyan et al. 2006, Pickering et al. 2002). In Brazil, sediment occurrences of hydrated aluminosilicate minerals with alkali and alkaline-earth metal are known to exist in northern areas of Brazil (Rezende and Angélica 1999). Despite their high-impurity content, applications of natural zeolitic concentrates in the agriculture present no major obstacle.

Massive agricultural activities require minimum nutrient fixation by the soil. This can only be accomplished if the rate of release from nutrient compounds match plants uptake (Park and Komarneni 1997, Mc- 
Dowell and Sharpley 2003, McGechan and Lewis 2002). The direct application of nutrients - especially potassium and nitrogen - is recognized as the main cause for their loss. In Brazil, alternative low-cost substrates are needed not only to prevent plant nutrient losses but also to attenuate phosphorus deficiency of Brazilian acidic soils and its fixation by the sesquioxidic $\left(\mathrm{Fe}_{2} \mathrm{O}_{3}\right.$ - and $\mathrm{Al}_{2} \mathrm{O}_{3}$-rich) clay. The precipitation of large amounts of highly soluble phosphorus compounds commonly used to complement Brazilian clay-rich soils became a major concern due to its ecological and economic implications (Melfi et al. 1999). Moreover, the nitrogen loss by volatilization of ammonia $\left(\mathrm{NH}_{3}\right)$ is one of the main factors for a low agronomic efficiency of urea, when applied directly on the surface of the soil. This common practice leads to the loss of nitrogen nutrient by ammonia evaporation that can reach extreme values, close to $80 \%$ (Conrad and Seiler 1980, DeKlein and van Logtestijn 1994). A reduction of this loss can be reached through the use of sources less susceptible to volatilization (nitric or ammoniac), or by soil incorporation of the urea (a process hindered by direct fertilization). Slow urea liberation have also been observed with the addition of acids, salts of $\mathrm{K}, \mathrm{Ca}$ and $\mathrm{Mg}$, and by the choice of specific urea's grain size distribution (Allaire and Parent 2004).

However, the production of urea is a high-cost process, starting with no renewable energy. Its use to provide nitrogen plant nutrient needs thus efficient processes with benefits that would not imply a retraction of the market of fertilizers in Brazil. These nutrient losses are sensitive to regional climatic conditions and soil type and no universal approach can meet their diversities. In the case of soil, the losses depend on clay concentrations, organic matter and cationic exchange capacity (van Straaten 2006, Jama and van Straaten 2006). Any development of this technology is highly strategic to Brazil because implies less agricultural dependence on fossil fuels and a contribution towards the mitigating of its environment impact.

In the present work it was shown how a low-cost treatment allowed the use of a natural zeolitic concentrate as soil amendment. The Materials and Methods section presents the characterization and methods used in the raw material treatment for the preparation of both chemical modified and non-modified zeolitic concen- trates. The next section describes the observed phosphate attachment and release properties of zeolitic concentrate (hereafter called the zeolite concentrate, ZC) and modified substrates in solutions of potassium phosphate. We report, in a following section, the first results obtained with this Brazilian sedimentary zeolite to reduce ammonia volatilization - loss of the nitrogen nutrient - in tropical farms. Preliminary laboratory tests were made with both ammonium sulfate and urea into $\mathrm{ZC}$. In the laboratory tests, the observations of the retention of ammonia by $\mathrm{ZC}$ were done using the photoacoustic set-up described in Baptista-Filho et al. (2007). The report data were obtained at temperatures from 25 to $60^{\circ} \mathrm{C}$, simulating temperatures excursions of tropical weather.

The objective of these assays was to characterize and evaluate the $\mathrm{P}$ and $\mathrm{N}$ nutrients' retention and release properties of a Brazilian sedimentary zeolitic concentrate. The present results indicate that the addition of the ZC concentrate should increase the agronomic efficiency of fertilizer applications in family-type cultivations. These cultivations represent a major fraction of the Brazilian agriculture production of about $50 \%$ (Leonardos et al. 2000).

\section{MATERIALS AND METHODS}

This section describes the main techniques used to characterize the zeolitic sediment, its concentration, and to chemically modify it to homoionic forms. In a previous communication, the zeolitic component was identified as stilbite of the heulandite group - ideal composition $(\mathrm{Na}, \mathrm{K}) \mathrm{Ca}_{2}\left[\mathrm{Al}_{5} \mathrm{Si}_{13} \mathrm{O}_{36}\right] \cdot 14 \mathrm{H}_{2} \mathrm{O}$. It should be also emphasized that sedimentary occurrence in sandstones covers a large area - the Parnaíba River basin embraces an area of about $1000 \mathrm{~km}^{2}$. A preliminary survey of this occurrence has been made by Goes et al. (1994) and Rezende and Angélica (1997, 1999). Due to its different formations (Brito Neves 1998), the stilbite concentration varies with sampling site (Rezende and Angélica 1999). The samples were collected near the city of Imperatriz, Maranhão State $\left(5^{\circ} 49^{\prime} 44^{\prime \prime}\right.$ south and $47^{\circ} 21^{\prime} 27^{\prime \prime}$ west). This region is one of the least populated of this state, well below its mean of about 19 inhabitants $/ \mathrm{km}^{2}$. Any attempt for industrial exploitation of this zeolitic occurrence should consider the present installations for 
exporting iron ore from nearby Carajás mines (of about 70 million tons per year). According to Rezende and Angélica (1997) there exist in Brazil three regions with sedimentary zeolite: (1) the Corda Formation in the Parnaíba Basin (the sampling site of the present work); (2) the Adamantina Formation of the Paraná River Basin, at the São Paulo state; and (3) the Botucatú Formation of the Paraná River Basin at the state of Mato Grosso do Sul. The Parnaíba Basin has the most significant occurrence of sedimentary zeolite in Brazil. The depth of this sediment varies widely, reaching $30 \mathrm{~m}$ deep in some points, and its zeolitic contents can reach $50 \%$.

The main techniques used to characterize the sediments were the classification by sieving followed by Tyler-series grain size selection from 295 to $37 \mu \mathrm{m}$. All fractions were analyzed by X-Ray diffraction, XRD, using a Siemens AXS D5005 diffractometer $\mathrm{Cu}-\mathrm{K} \alpha$ radiation and parallel geometry.

The composition of the head samples were carried out by X-ray fluorescence with a Philips spectrometer model PW2400 and by XRD using a Bragg-Bretano Siemens type-F diffractometer $(\mathrm{Cu}-\mathrm{K} \alpha$ radiation) with a Philips 1830/25 high-stability voltage supplier. The XRD numerical simulations were done with the DBWSprogram developed by Young et al. (1995).

In this work, three different techniques were used to separate the main components of the head sample: vibratory table, Deister, model RA15SSD, Humphrey spiral, model MD, and high magnetic-field separation of iron oxide covered silicates, separator model Boxmag Rapid. Each identified product was characterized by dense media technique in order to quantify the separation efficiency (Wills 1985). Specific surface area (BET) determinations were done with an ASAP 2000 apparatus from Micromeritics Instruments Corporation. In the assays of phosphate attachment and release, the observation of the $\mathrm{PO}_{4}^{3-}$ signature was done by atomic absorption spectrometry (AAS), Varian model 55B. Specific phosphorous determinations were done with UV/VIS spectrometry, HACH model DR/2010. A greenhouse equipped with temperature and humidity controls was used for the preliminary plant assays using modified concentrates - ZC-Na and Zeo-K - described in Section 2(c) below. Chemical analysis and treatments shall be presented in the next subsections.
CHARACTERIZATION AND CONCENTRATION of ZeOlitic Sediment (ZC)

The sediments collected in the Parnaíba Basin occurrence were homogenized, split, crushed and sieved to obtain particles with diameter less than $4.67 \mathrm{~mm}$. The separation of their light components was done with a vibratory table and a Humphrey spiral. The classification of these head samples according to their zeolitic concentrate content was done using dense medium technique and X-ray diffraction (XRD). These observations revealed that all the denser rejects obtained from the separation process are essentially quartz coated with iron oxide. The XRD determinations are consistent with the AAS results.

These analyses demonstrate that the zeolitic sediment and quartz are the major components of those head samples. Figure 1 shows a diffractogram of the selected sedimentary head sample used in present work. This head sample contains the zeolite stilbite mixed with smectitic clay deposits. X-ray diffraction was used in the determination of the mineral composition. A characterization with $\mathrm{X}$-Ray diffraction shows the presence of stilbite (ideal formula, $(\mathrm{Na}, \mathrm{K}) \mathrm{Ca}_{2}\left[\mathrm{Al}_{5} \mathrm{Si}_{13} \mathrm{O}_{36}\right] .14 \mathrm{H}_{2} \mathrm{O}$ ) as one of the main mineral components.

Preparation of the NATURAL ZEOLitic CONCENTRATE (ZC)

As mentioned in the previous section, vibratory table and Humphrey spiral were used to separate out the quartz particles from the zeolitic component of the head samples of the sediment. Another separation method using the sample ferromagnetic behavior - probably due to ferric oxide coating - could provide a simple process for particle separation, but this coating is also present in a fraction of the stilbite/smectite particles. Yet, the magnetic separation could be considered to concentrate field samplings of the sediment. Table I below compares the yields of zeolitic concentrates using these three separation methods for the same of head sample. As shown in Table I, a high zeolitic concentration could be obtained using a low-cost mechanical separation technique (vibratory table) yielding a recovery of approximately $67 \%$.

The ZC chemical composition (weight fraction) is given in Table II(a) (main components) and in Table II(b) (minor components). In Table II(a), the presence of $\mathrm{K}_{2} \mathrm{O}$ 

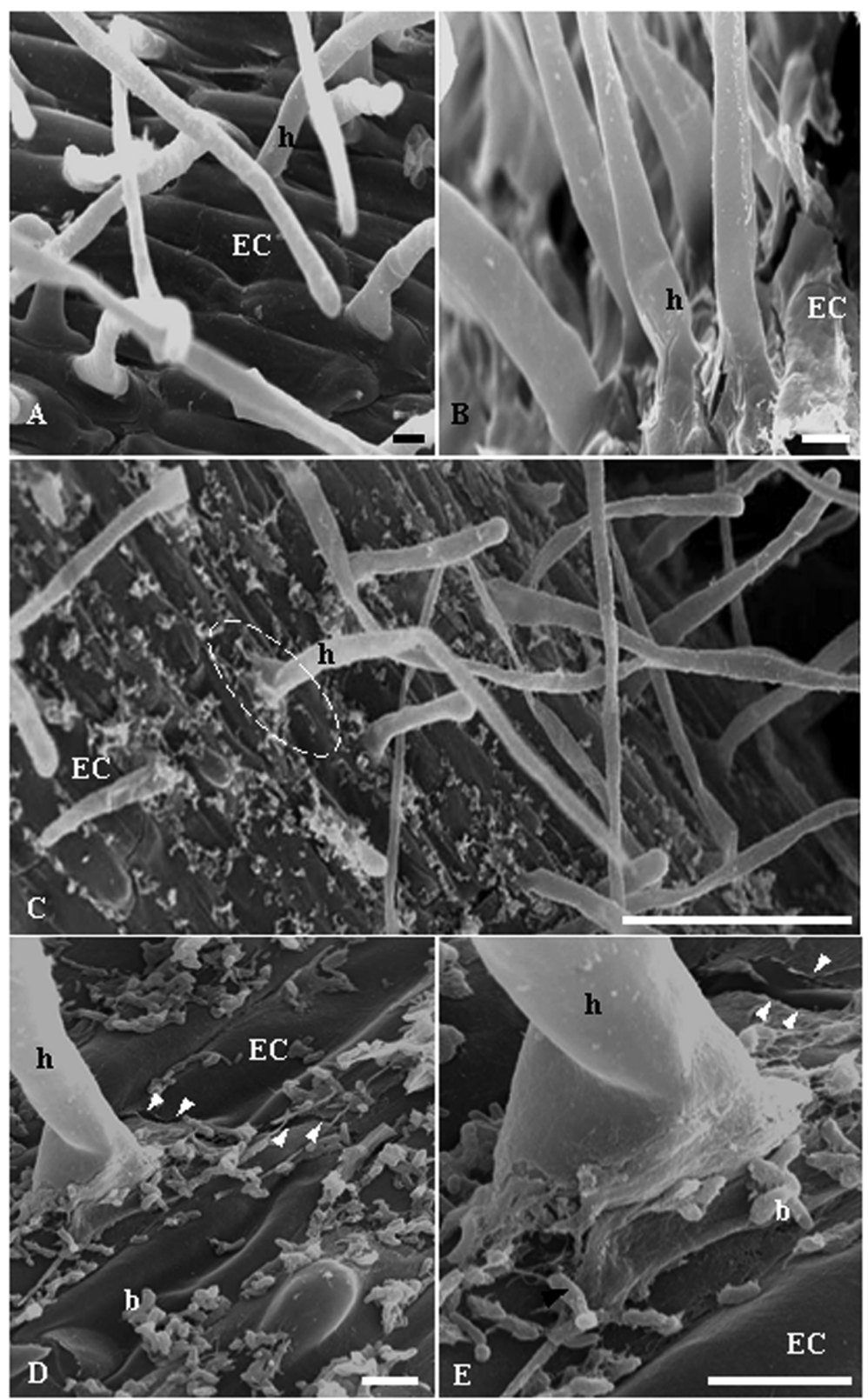

Fig. 1 - Transmission Electron Microscopy micrograph of the head sample showing features of the smectitic clay, the zeolite and some dentritic constituents. (Rezende and Angélica 1999). This image shows a grain surface of the sediment where some smectite remains adhered. This smectite film - with its honeycomb like texture - covers the grain.

and $\mathrm{MgO}$ in the chemical composition of the head sample can be associated with the clay (smectitic) deposit of the sediment. This was confirmed by the intercalation process as shown in Figure 2. In this figure, the basal spacing variation of about $2 \AA-$ due to etanodiol1,2 (glycol) intercalation - is in agreement with reported values for this clay (van Olphen 1977). Figure 3 is a TEM micrograph of the concentrate showing the zeolite (stilbite) intertwined with smetitic clay.

In order to obtain a Na- homoionic state for ZC obtained with the vibratory table, $25 \mathrm{~g}$ of the concentrate was suspended in a $250 \mathrm{~mL}$ solution of $\mathrm{NaCl} 2 \mathrm{~N}$ 
TABLE I

A comparison of the separation methods.

\begin{tabular}{c|c}
\hline $\begin{array}{c}\text { Separation } \\
\text { method }\end{array}$ & $\begin{array}{c}\text { Zeolitic } \\
\text { concentrate (\%) }\end{array}$ \\
\hline Magnetic & 41.8 \\
\hline Humphrey spiral & 59.1 \\
\hline Vibrating table & 66.8 \\
\hline
\end{tabular}

TABLE II(a)

Chemical composition of $\mathrm{ZC}$ (weight fractions of main components).

\begin{tabular}{c|c|c|c|c|c|c|c|c|c}
\hline $\mathrm{SiO}_{2}$ & $\mathrm{Al}_{2} \mathrm{O}_{8}$ & $\mathrm{Na}_{2} \mathrm{O}$ & $\mathrm{K}_{2} \mathrm{O}$ & $\mathrm{CaO}$ & $\mathrm{MgO}$ & $\mathrm{Fe}_{2} \mathrm{O}_{3}$ & $\mathrm{P}_{2} \mathrm{O}_{5}$ & $\mathrm{TiO}_{2}$ & $\mathrm{BaO}$ \\
\hline 64.7 & 12.7 & 0.8 & 0.97 & 3.1 & 1.5 & 3.3 & 0.12 & 0.60 & 0.12 \\
\hline
\end{tabular}

TABLE II(b)

Chemical composition of ZC (weight fractions of minor components).

\begin{tabular}{c|c|c|c|c}
\hline $\mathrm{Co}$ & $\mathrm{NiO}$ & $\mathrm{ZnO}$ & $\mathrm{Cr}_{2} \mathrm{O}_{3}$ & $\mathrm{MnO}$ \\
\hline 0.02 & $<.01$ & $<.01$ & 0.05 & 0.06 \\
\hline
\end{tabular}

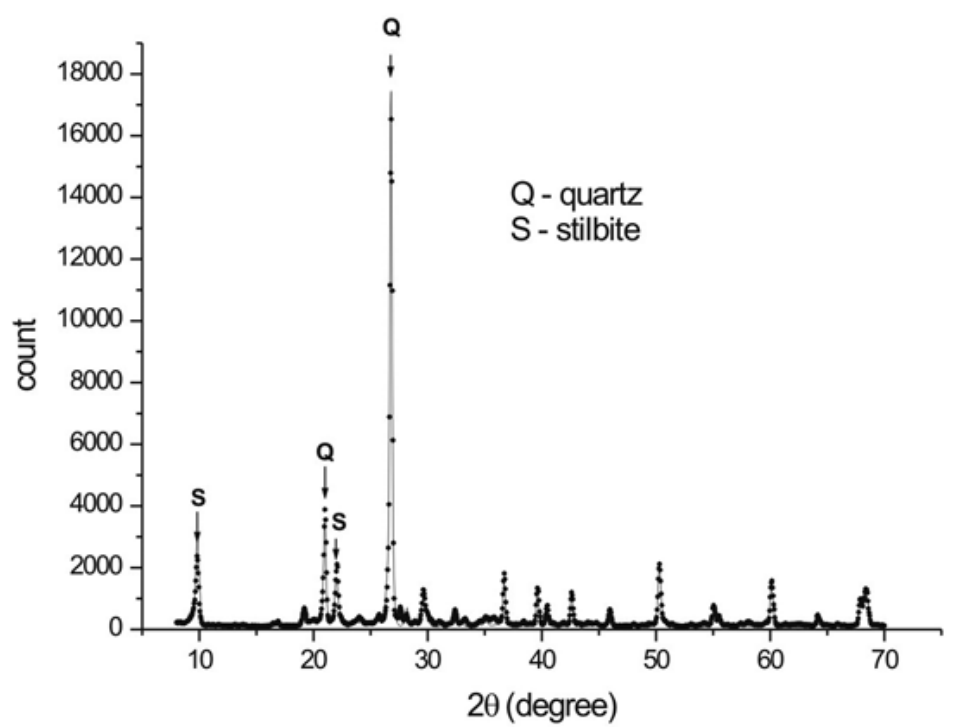

Fig. 2 - The X-ray diffraction patterns ( $\mathrm{K} \alpha-\mathrm{Cu}$ radiation) of the main constituents of the head sample, Q (quartz) and S (stilbite). The line is a Rietveld fit to the data points.

and stirred for $24 \mathrm{~h}$ at $100^{\circ} \mathrm{C}$. The suspension was then filtered and dried at $100^{\circ} \mathrm{C}$. The cationic exchange capacities (CEC) were determined by Na displacement by $\mathrm{K}$ cation. $1 \mathrm{~g}$ of each of the two ZC samples - the original and heat-treated one - was suspended in $40 \mathrm{~mL}$ of IM KCl. These suspensions were then filtered and dried at $100^{\circ} \mathrm{C}$ and the cationic amounts determined by atomic absorption spectrometry (AAS).
At this concentration there is an increase of cationic exchange capacity (CEC) - from a value of about $1.69 \mathrm{meq} / \mathrm{g}$, for the head sample, to $2.55 \mathrm{meq} / \mathrm{g}$, for the ZC. The concentrates prepared with the vibrating table were chosen for the sorption/release assays described in this report.

Figure 4 shows a comparison of the ZC molecular composition with those of similar commercial products. 


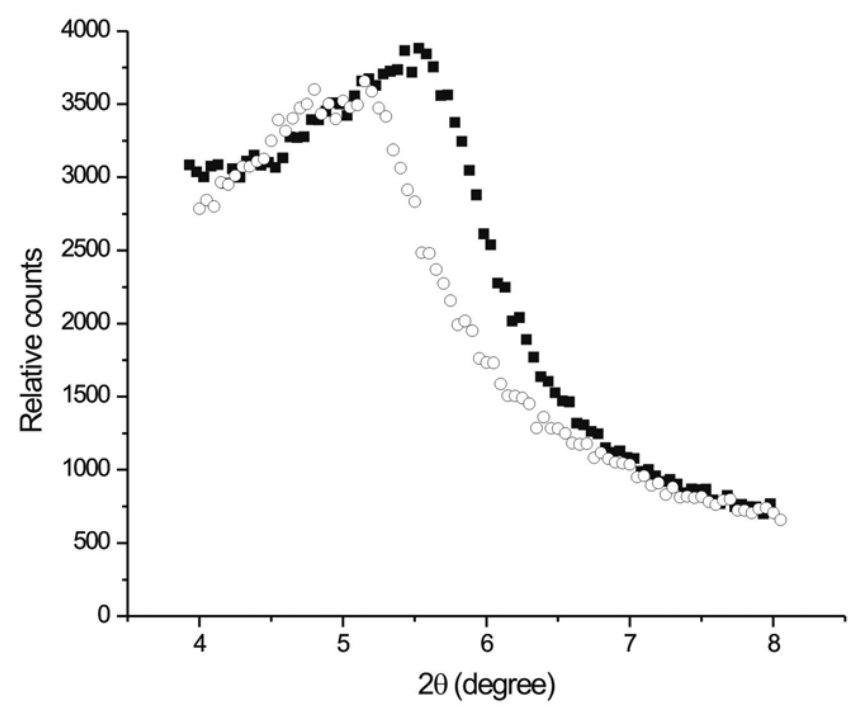

Fig. 3 - Bragg reflection ( $\mathrm{K} \alpha-\mathrm{Cu}$ radiation) in basal planes of the smectite due to the intercalation of etanodiol-1,2 (glycol). The open circles and solid squares are the data before and after intercalation, respectively.

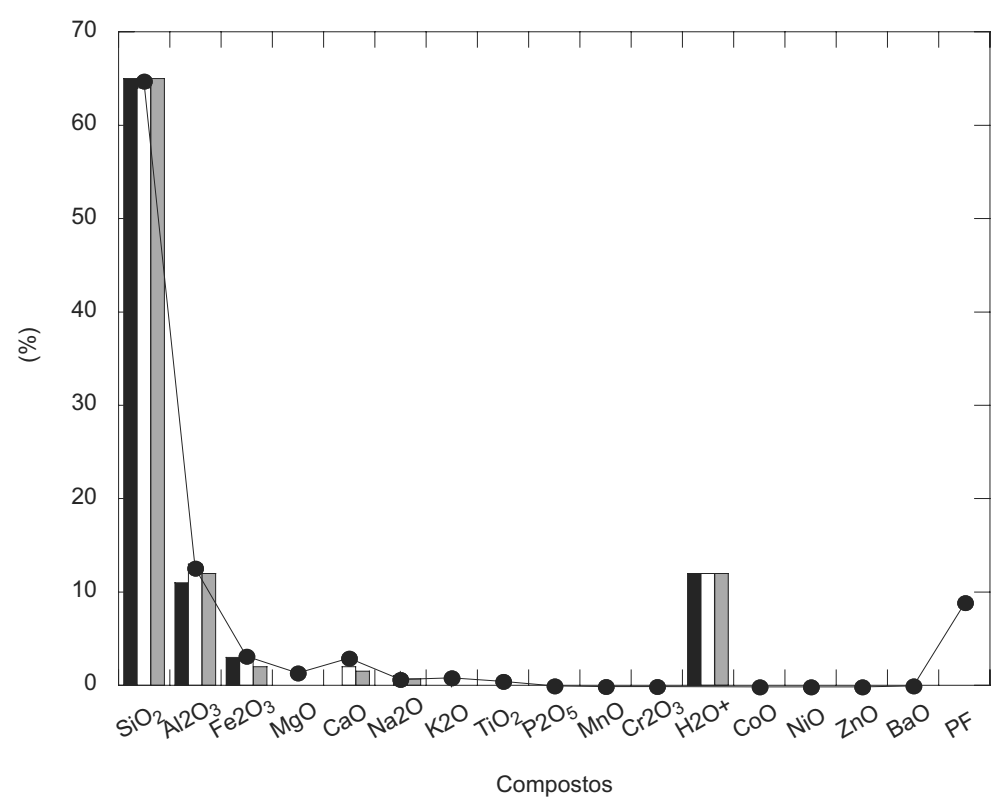

Fig. 4 - A comparison of the sedimentary Brazilian zeolitic composition with those from different sources: US (dark bars); Loumavida/Chile (white bars); Tasajera/Cuba (grey bars); and European (dark circles).

It can be seen in this figure that all the compositions are very similar to each other, suggesting that the Brazilian natural zeolitic concentrate might be considered for applications that tolerate its impurity content. As mentioned above, the removal of the dominant sample impurity, quartz, is not complete and no obvious low-cost technique could be found to extract residual oxides and the smectitic clay. As mentioned previously, the chemical analysis of the concentrate shown in Tables II(a) and (b) reviews the presence of the smectitic component $\left(\mathrm{MgO}\right.$ and $\mathrm{K}_{2} \mathrm{O}$ ).

The determinations of the specific surface area (BET) and porous volume of the ZC samples were made with preheated samples of the concentrate at $200^{\circ} \mathrm{C}$ in 
order to remove humidity and any volatile material; the measures values are in Table III.

TABLE III

The BET values for $\mathrm{ZC}$ microporous volume and specific area.

\begin{tabular}{c|c|c}
\hline $\begin{array}{c}\text { Microporous } \\
\text { volume } \\
\left(\mathrm{cm}^{3} / \mathrm{g}\right)\end{array}$ & $\begin{array}{c}\text { Microporous } \\
\text { area } \\
\left(\mathrm{m}^{2} / \mathrm{g}\right)\end{array}$ & $\begin{array}{c}\mathrm{ZC} \\
\text { surface area } \\
\left(\mathrm{m}^{2} / \mathrm{g}\right)\end{array}$ \\
\hline 0.0057 & 12.09 & 9.71 \\
\hline
\end{tabular}

\section{Preparation of Modified Concentrates}

The main objectives of these chemical treatments were to observe the correlation between the increase of cationic exchange capacity, CEC, of the concentrate and plants' nutrient uptake. This conventional method was executed in order to evaluate the behavior of stilbite as a standard sorbent product, although this material contained a low-grade class of zeolite. Among the existing methods to modify the CEC of mineral sediment, the $\mathrm{K}$ - or Na-salt treatments were chosen to achieve their respective homoionic forms. For this purpose, ZC was dispersed into solutions containing either $\mathrm{NaCl} 0.5 \mathrm{~N}$ or $\mathrm{KNO}_{3} 0.5 \mathrm{~N}$, in a 1:10 weight proportion. The suspensions were stirred for $24 \mathrm{~h}$, at room temperature, centrifuged and filtered. The modified concentrates - hereafter identified as ZC-Na and Zeo-K - were dried at $100^{\circ} \mathrm{C}$. Determinations of both sodium and potassium contents in this zeolitic concentrate were determined from the analysis of supernatants using atomic absorption spectroscopy (AAS). The amounts, Q, of incorporated $\mathrm{Na}$ and $\mathrm{K}$ are summarized in Table IV. Table $\mathrm{V}$ shows that the sediment behaves as a standard zeolite, exhibiting a CEC improvement in its homoionic form. Further results have also shown that the Na-modified zeolitic concentrate ( $\mathrm{ZC}-\mathrm{Na})$ has an increase of potassium content when compared with the non-modified $\mathrm{ZC}$ (2.55 meq/g).

\section{THE LABORATORY ASSAYS FOR P AND K ATTACHMENT AND RELEASE}

Assays of Phosphate $\left(\mathrm{PO}_{4}^{3-}\right)$ ATtAChMENT AND RELEASE

This section describes the observed phosphate attachment properties of the ZC substrate. The assays were done with potassium phosphate $\left(\mathrm{K}_{2} \mathrm{HPO}_{4} \quad 1 \mathrm{M}\right.$ and $0.01 \mathrm{M}$ ) in the 1:40 proportions. These preliminary results confirmed the expectations that the sediment exhibits the well-known ionic exchange behavior of standard zeolite products. As shown below, it was observed that non-modified $\mathrm{ZC}$ has lower $\mathrm{PO}_{4}^{3-}$ incorporation than its homoionic form (Zeo-K).

TABLE IV

$\mathrm{Na}$ and $\mathrm{K}$ contents in modified $\mathrm{ZC}$.

\begin{tabular}{l|l}
\hline Sodium & $\mathrm{Q}_{\mathrm{Na}}=3 \mathrm{mg} / \mathrm{g}$ of $\mathrm{ZC}-\mathrm{Na}$ \\
\hline Potassium & $\mathrm{Q}_{\mathrm{K}}=25 \mathrm{mg} / \mathrm{g}$ of $Z \mathrm{eo}-\mathrm{K}$ \\
\hline
\end{tabular}

TABLE V

Properties of the Na-modified ZC (ZC-Na).

\begin{tabular}{l|l}
\hline Incorporated potassium per $\mathrm{g}$ & $\mathrm{Q}_{\mathrm{K}}=128 \mathrm{mg} / \mathrm{g}$ \\
\hline Cationic exchange capacity per $\mathrm{g}$ & $\mathrm{CEC}_{\mathrm{T}}=3.3 \mathrm{meq} / \mathrm{g}$ \\
\hline
\end{tabular}

The laboratory tests of $\mathrm{PO}_{4}^{3-}$ capture had the following protocol: $1 \mathrm{~g}$ of concentrated $\mathrm{CZ}$ in solutions of potassium phosphate $\left(\mathrm{K}_{2} \mathrm{HPO}_{4} 1 \mathrm{M}\right.$ and $\left.\mathrm{K}_{2} \mathrm{HPO}_{4} 0.01 \mathrm{M}\right)$ in the 1:40 proportion is kept at RT with constant agitation, for $24 \mathrm{~h}$. The material was then filtered, and the supernatants analyzed by AAS. This test was repeated with the modified zeolitic concentrate (ZEO-K). Table VI displays the results obtained with the $\mathrm{K}_{2} \mathrm{HPO}_{4}$ solutions.

TABLE VI

$$
\mathrm{PO}_{4}^{3-} \text { attachment in zeolitic concentrate }
$$
and modified substrates.

\begin{tabular}{c|c|c}
\hline $\begin{array}{c}\mathrm{K}_{2} \mathrm{HPO}_{4} \\
\text { concentration }\end{array}$ & $\begin{array}{c}\mathrm{ZC} \\
(\mathrm{mg} / \mathrm{g})\end{array}$ & $\begin{array}{c}\mathrm{ZEO}-\mathrm{K} \\
(\mathrm{mg} / \mathrm{g})\end{array}$ \\
\hline $0.01 \mathrm{M}$ & 5.15 & 4.90 \\
\hline $1 \mathrm{M}$ & 120 & 278.2 \\
\hline
\end{tabular}

As it can be seen in Table VII, the results obtained with the solution of $0.01 \mathrm{M}$ of $\mathrm{K}_{2} \mathrm{HPO}_{4}$ show no clear trend. This might be caused by the $\mathrm{PO}_{4}^{3-}$ competition of impurities present in this natural sediment.

Assays of Phosphate Attachment:

NON-MODIFIED ZC

The $\mathrm{K}_{2} \mathrm{HPO}_{4}$ was also used for the attachment and release assays with $\mathrm{ZC}$ in aqueous solutions of (a) $\mathrm{K}_{2} \mathrm{HPO}_{4}(0.57 \mathrm{M}, 0.014 \mathrm{M}$ and $0.029 \mathrm{M})$ in $\mathrm{NH}_{4} \mathrm{NO}_{3}$ $0.05 \mathrm{M}$. In the $\mathrm{PO}_{4}^{3-}$ attachment determinations, aliquots 
TABLE VII

Phosphate attachment onto natural and modified $\mathrm{ZC}$ in solutions of $\mathrm{K}_{2} \mathrm{HPO}_{4}$ 0.01M.

\begin{tabular}{c|c}
\hline Products & $\begin{array}{c}\text { Adsorbed amounts } \\
\text { of phosphate }\end{array}$ \\
\hline $\mathrm{ZC}$ & QPO4 $_{\mathrm{P}}=6.52 \mathrm{mg} / \mathrm{g}$ \\
\hline $\mathrm{ZC}-\mathrm{Na}$ & $\mathrm{Q}_{\mathrm{PO} 4}=5.15 \mathrm{mg} / \mathrm{g}$ \\
\hline $\mathrm{Zeo}-\mathrm{K}$ & $\mathrm{Q}_{\mathrm{PO} 4}=4.90 \mathrm{mg} / \mathrm{g}$ \\
\hline
\end{tabular}

of aqueous solutions within the range of $0.5 \mathrm{~mL}$ to $40 \mathrm{~mL}$ were mixed with $4 \mathrm{~g}$ of the zeolitic concentrate in centrifuge tubes. Two sets of tubes were each filled to a total amount of $40 \mathrm{~mL}$ with, respectively, water and the solution of $\mathrm{NH}_{4} \mathrm{NO}_{3} 0.05 \mathrm{M}$. The tubes were agitated $200 \mathrm{cycles} / \mathrm{s}$ for 48 hours and then centrifuged at $4500 \mathrm{rpm}$ for 15 minutes.

\section{Assays of Phosphate Release: Non-Modified ZC}

The release determinations followed the same procedure described above for the attachment assays. After the period of incubation and supernatant extraction, the residuals from the centrifuge tubes were washed with the same aqueous medium - either water or $\mathrm{NH}_{4} \mathrm{NO}_{3}$ $0.05 \mathrm{M}$. The residue was dispersed in $20 \mathrm{~mL}$ of either water or solution of $\mathrm{NH}_{4} \mathrm{NO}_{3} 0.05 \mathrm{M}$, agitated for $2 \mathrm{~h}$ at $200 \mathrm{c} / \mathrm{s}$, and then centrifuged. The supernatant was then transferred to a $100 \mathrm{~mL}$ reservoir. This procedure was repeated five times and the analysis of the $100 \mathrm{~mL}$ of supernatant was performed using the AAS.

\section{Assays of Phosphate Release: Modified ZC}

Table VIII below shows the main features of the phosphate release observed in this work with modified zeolitic concentrate substrates. The data shown in this table reveal that, within the time of observation, the phosphate release from the concentrates is a stead process.

\section{Assays for Ammonia Attachment and Release}

For the test results using ammonium sulfate, the samples were prepared by mixing $1250 \mathrm{mg}$ of ZC (or natural quartz sample) in an aqueous ammonium sulfate $\left(\left(\mathrm{NH}_{4}\right)_{2} \mathrm{SO}_{4}\right)$ solution, in the concentration of $7.2 \mathrm{~g} / \mathrm{L}$. The mixture was mechanically agitated during $180 \mathrm{~min}-$ utes at room temperature. Natural quartz samples were used to contrast the ammonia retaining power of the $\mathrm{ZC}$.
Using nitrogen as the carrier gas, ammonia emitted from the ammonia enriched $\mathrm{ZC}$ was taken into a differential photoacustic cell. By using an electronic mass flow controller, the sample flow was kept constant at $5 \mathrm{~L} / \mathrm{h}$ (Baptista-Filho et al. 2007). The experimental set-up was calibrated by means of a standard sample containing $5 \mathrm{ppm}$ of ammonia diluted in nitrogen. The temperature analysis at $60^{\circ} \mathrm{C}$ was achieved using a home-made resistive oven.

\section{RESULTS}

A set of assays was made in order to observe the capture competition between phosphorous and potassium compounds. These key plant nutrients were presented in the assays as $\mathrm{K}_{2} \mathrm{HPO}_{4}$. $\mathrm{P}$ - and $\mathrm{K}$-capture rates were observed in absence and in the presence of ammonium nitrate $\left(\mathrm{NH}_{4} \mathrm{NO}_{3}\right)$ 0.05M. The $\mathrm{ZC}$-capture time courses in an aqueous medium and in an ammonium nitrate medium are shown in Figures 5 and 6, respectively. In Figure 5 it is presented the capture time-course of $\mathrm{K}^{+}$. The $\mathrm{ZC}$ capture of $\mathrm{PO}_{4}^{3-}$ is shown in the Figure 6. In the aqueous medium (Fig. 5) $\mathrm{P}$ and $\mathrm{K}$ attachment saturations are reached within $6 \mathrm{~h}$, and their profiles are fairly similar. For ammonium nitrate medium (Fig. 6) saturation is also reached within $6 \mathrm{~h}$ but $\mathrm{P}$ attachment remains always larger than that for potassium.

In Figures 7 and 8 , the $\mathrm{K}^{+}$and $\mathrm{PO}_{4}^{3-}$ attachments - in aqueous and the ammonium nitrate media respectively - are plotted against equilibrium concentration. In aqueous medium (Fig. 7), the potassium and phosphate captures have trends suggestive of different attachment mechanisms. The $\mathrm{K}_{2} \mathrm{HPO}_{4}$ release data shown in Figure 9 were obtained with same water and ammonium nitrate electrolytes. In an aqueous medium (Fig. 9, left panel), $P$ release is greater than that obtained for phosphate. The reversed behavior is observed with the ammonium nitrate medium. In this case, the P release shows a steep increase for low concentrations while the onset of potassium release can only be observed for concentrations beyond $\sim 20 \mathrm{mg} / \mathrm{L}$. The results shown in Figure 10 suggest that the $\mathrm{PO}_{4}^{3-}$ releases from both Zeo-K and $\mathrm{ZC}$ are slow processes - a requisite for a plant nutrient amendment.

Figure 11 shows the temperature effect on the ammonia emission rate from the $\mathrm{ZC}$ and sand substrates. As 
TABLE VIII

Time courses of $P$ release from natural and modified $Z C$.

\begin{tabular}{c|c|c|c|c|c|c}
\hline \multirow{2}{*}{ Concentrates } & \multicolumn{7}{|c}{ Time (min) } \\
\cline { 2 - 7 } & 30 & 60 & 90 & 120 & 180 & 240 \\
\hline Zeo-K & 278.2 & 275.4 & 274.0 & 272.0 & 270.8 & 270.0 \\
\hline ZC & 51.2 & 47.5 & 46.0 & 43.8 & 42.6 & 41.4 \\
\hline ZC-Na & 120.0 & 114.0 & 112.3 & 111.1 & 109.3 & 106.6 \\
\hline
\end{tabular}

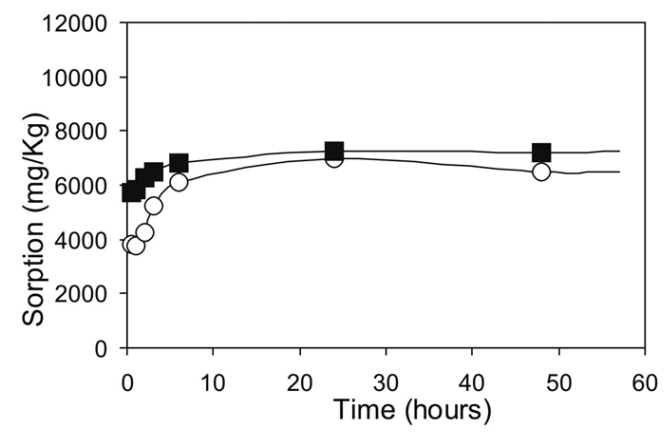

Fig. 5 - A time course of $\mathrm{K}^{+}$(solid squares) and $\mathrm{PO}_{4}^{3-}$ (open circles) attachments by the zeolitic concentrate $(\mathrm{ZC})$ in the absence of $\mathrm{NH}_{4} \mathrm{NO}_{3}$ electrolyte.

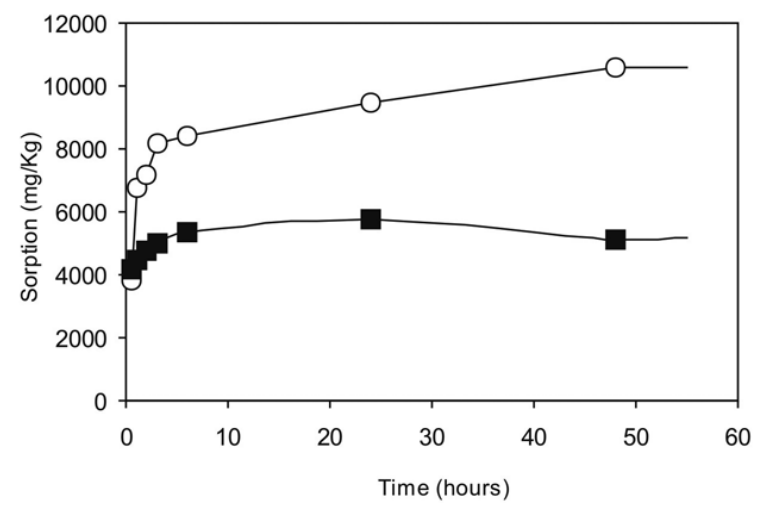

Fig. 6-A time course of $\mathrm{K}^{+}$(solid squares) and $\mathrm{PO}_{4}^{3-}$ (open circles) attachments by the zeolitic concentrate (ZC) in the presence of $\mathrm{NH} 4 \mathrm{NO} 3$ electrolyte.

expected, the emission rate increases with the temperature. The temperature interval simulates an extreme day to night variation even for tropical countries. These results demonstrate that: i) an efficient ammonia sorption occurs in the $\mathrm{ZC}$; and ii) the retention mechanism is not the chemical complexation.

\section{DISCUSSION}

The nutrient attachment assays show that the natural zeolitic concentrate in the homoinic form yields the best results. The assays with phosphate nutrient show that the addition of $\mathrm{KNO}_{3}$ to modified zeolitic concentrate doubles its yield, resulting in fivefold overall increase when compared with that of non-homoionic natural zeolitic concentrate.

For non-modified zeolitic concentrates, the results of the attachment assays of the Section 3 reveal a higher $\mathrm{P}$ selectivity, suggesting that phosphate complexes are at the concentrate surface. Moreover, the fairly distinct trend observed for phosphate attachment for concentrations higher than $\sim 200 \mathrm{mg} / \mathrm{L}$ (Fig. 7), can be interpreted as the onset of a phosphate co-precipitation mechanism. 


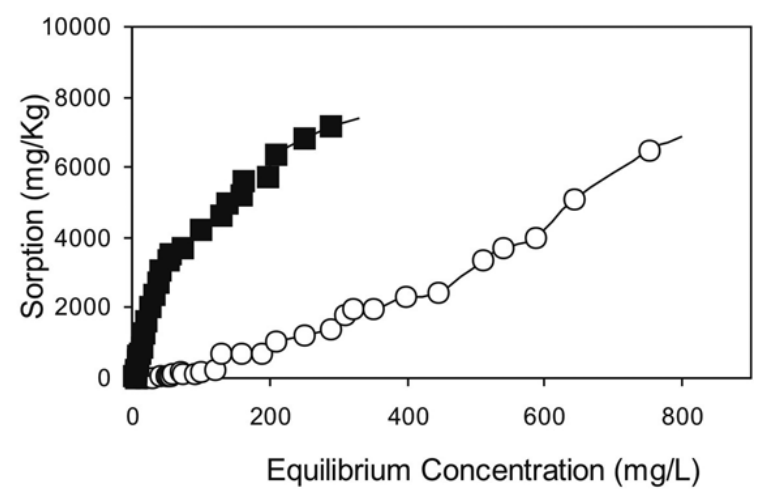

Fig. 7 - ZC uptakes of $\mathrm{K}^{+}$(solid squares) and $\mathrm{PO}_{4}^{3-}$ (open circles) in the absence of electrolytes.

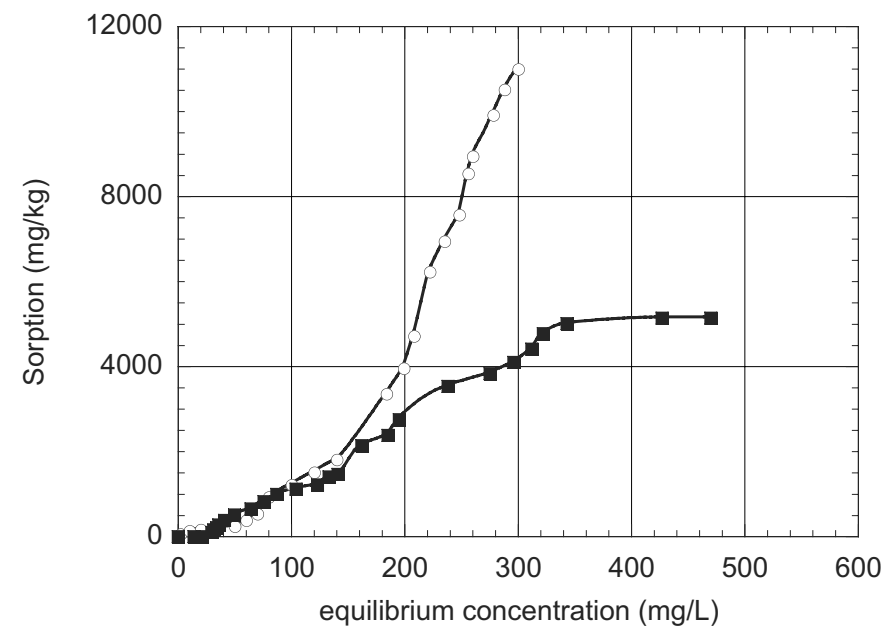

Fig. 8 - $\mathrm{ZC}$ uptakes of $\mathrm{K}^{+}$(solid squares) and $\mathrm{PO}_{4}^{3-}$ (open circles) in the presence of $\mathrm{NH}_{4} \mathrm{NO}_{3}$ electrolyte.

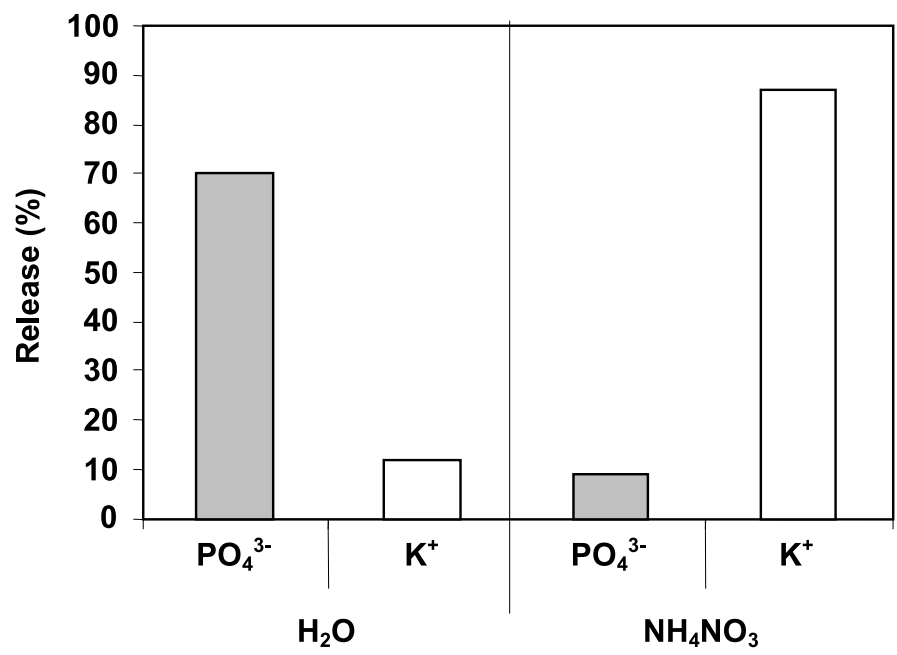

Fig. 9 - The $\mathrm{K}_{2} \mathrm{HPO}_{4}$ release obtained in the same suspensions of water and of ammonium nitrate solution: $\mathrm{PO}_{4}^{3-}$ (grey bars); $\mathrm{K}+$ (white bars). 


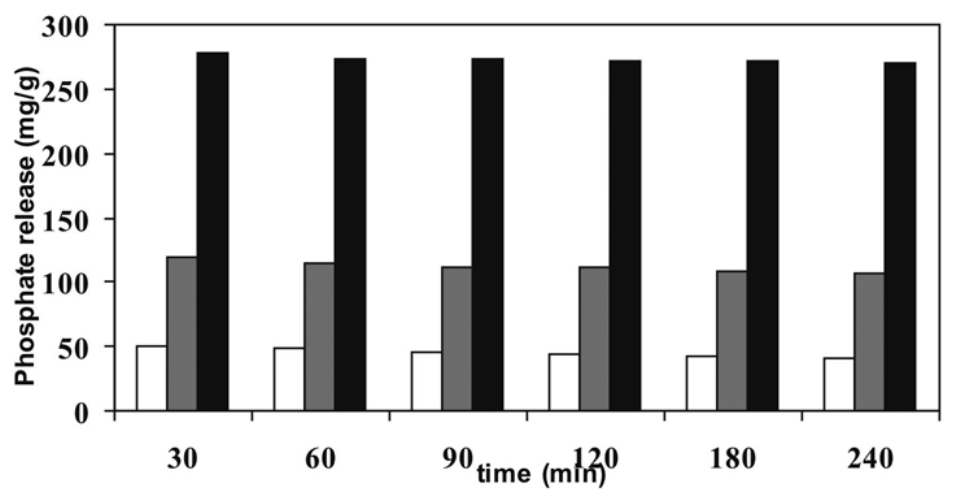

Fig. 10 - Time courses of phosphate release from the three forms of substrates previously suspended in the same phosphate solution. The bars indicate: a) the modified with potassium nitrate, Zeo-K, (black bars); b) non-modified concentrate, $\mathrm{ZC}$, (white bars); and c) the homoionic form (Na), ZC-Na, (gray bars).

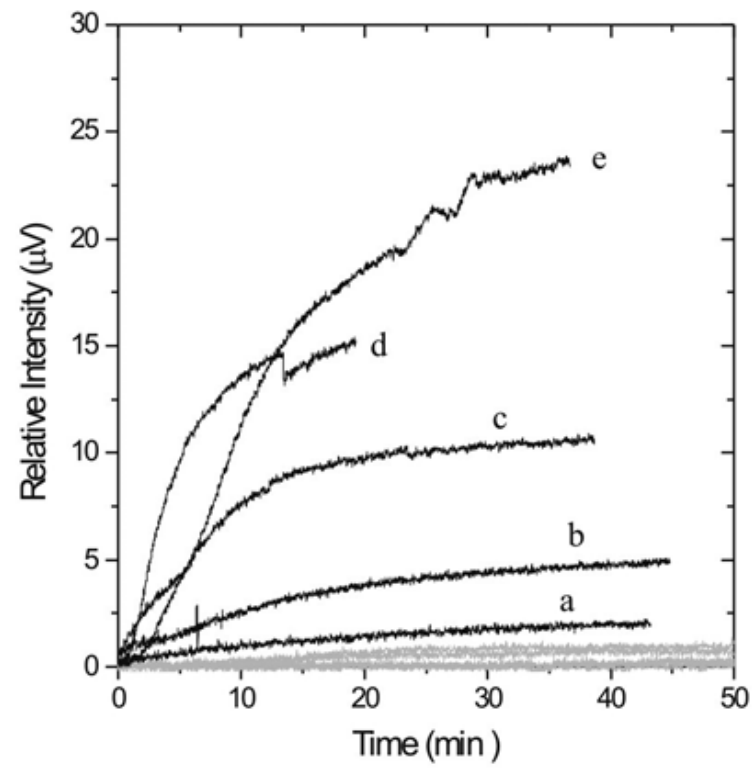

Fig. 11 - Time evolution of ammonia gas released from $\mathrm{ZC}$ under different temperatures: $25^{\circ} \mathrm{C}(\mathrm{a}) ; 30^{\circ} \mathrm{C} \mathrm{(b)} ; 40^{\circ} \mathrm{C}(\mathrm{c}) ; 50^{\circ} \mathrm{C}(\mathrm{d})$ and $60^{\circ} \mathrm{C}(\mathrm{e})$. The lowest intensity curve is the observed ammonia retention in a sand substrate. The large gap in this figure shows that, at $60^{\circ} \mathrm{C}$, most of the ammonia has been released.

The trends observed with the release assays with non-modified zeolitic concentrates suggest that $\mathrm{P}$-attachment in this medium might take place by a co-precipitation mechanism onto the zeolitic concentrate surface (Monte et al. 2003).

The chemical and XRD studies described above show that this Brazilian natural zeolitic concentrate has properties close to those of mordenite that is intensively used in agro-industry (New Zealand Natural Zeolite 2004)

The attachment assays with non-modified zeolitic concentrates reveal a greater $\mathrm{HPO}_{4}^{2-}$ selectivity by the natural $\mathrm{ZC}$, when dispersed in an ammonium nitrate solution. This suggests that charge compensation might be required in order to achieve efficient phosphate anchorage by this zeolitic concentrate - a requirement to 
be met for its use as soil conditioner. Evidences of phosphate co-precipitation - a process that favors noncomplexation of the sorbed material onto the surface of the material - are suggested by the release assays with non-modified ZC.

\section{CONCLUSIONS}

We report the application of a natural rock-granulated zeolite as a slow plant-nutrient releaser. This sedimentary rock is found at the Parnaíba Basin, in the northern Brazil region. The characterization of the head samples shows that it is composed of the zeolite stilbite intertwined with a smectitic clay mineral, mixed with quartz. The use of low-cost quartz separation techniques and of conventional treatments yield plant-nutrient attachment and release properties matching those reported for similar commercial zeolitic products.

The field assays with modified zeolitic concentrates yield promising results. Their small scale and the applied ambient controls prevent further conclusions in connection with its applications in the agro-industry. Finally, the $\mathrm{N}$ losses through the process of $\mathrm{NO}_{3}$ lixiviation would also be minimized by the presence of this sedimentary concentrate. Extensions of this work to natural field conditions and larger scale shall be reported in this series.

Family-type cultivations - characterized by their small capital investments - represent about $50 \%$ of the Brazilian agriculture production (Leonardos et al. 2000). The direct application of nutrients in these cultivations is recognized as the main cause for their loss and dispersal to the environment. The present low-cost substrate could be used to mitigate these plant nutrient losses and, consequently, their environmental impact.

\section{ACKNOWLEDGMENTS}

The authors thank Dr. V. Soares for his artwork contributions. This work was supported by grants from the Brazilian Agencies: Conselho Nacional de Desenvolvimento Científico e Tecnológico (CNPq), Financiadora de Estudos e Projetos (FINEP), Fundação Carlos Chagas Filho de Amparo à Pesquisa do Estado do Rio de Janeiro (FAPERJ) and Fundação Universitária José Bonifácio (FUJB), Universidade Federal do Rio de Janeiro (UFRJ).

\section{RESUMO}

São apresentadas as propriedades físico-químicas de uma ocorrência sedimentar da Bacia do Parnaíba, Brasil, da zeólita estilbita, agregada a uma argila esmectítica. As amostras de diferentes sítios apresentam uma ampla variação do mineral zeolítico: entre $15 \%$ a $50 \%$. A utilização de espirais concentradoras foi suficiente para obtenção de concentrados contendo até $67 \%$ do mineral. Ensaios laboratoriais do concentrado dopado com fertilizantes revelam taxas de liberação de nutrientes comparáveis aos obtidos com produtos comerciais similares.

Palavras-chave: zeólita sedimentar, Bacia do Parnaíba, fertilizantes, minerais - captura e liberação de nutrientes.

\section{REFERENCES}

Allaire SE AND PARENT LE. 2004. Physical properties of granular organic-based fertilizers. Part 1 Static properties. Biosyst Eng 87: 79-87.

Baptista-Filho M, Silva MG DA, Luna F, Monte MBM, Souza-Barros F de, Polidoro JC, Miklós A AND VARGas H. 2007. Detection of ammonia released from zeolite by the quantum cascade laser based photoacoustic set-up. In: HASSAN TALAAK (Ed), $14^{\text {th }}$ International Conference on Photoacoustic and Photothermal Phenomena, Cairo, Egypt.

BRito NeVEs BB. 1998. The cambroordovician of the Borborema Province. Boletim IG - Série Científica. 29: 175193, USP, São Paulo, Brasil.

CONRAD R AND SEILER W. 1980. Field Measurements of the loss of fertilizer nitrogen into the atmosphere as nitrous oxide. Atmos Environ A-Gen 14: 535-558.

DeKlein CAM And VAn Logtestijn RSP. 1994. Denitrification in the top soil of managed grasslands in the Netherlands in relation to soil type and fertilizer level. Plant Soil 163: 33-44.

Gasparyan TA, Karamyan GG, Aleksanyan GM AND REVAZYAN LR. 2006. New organo-zeolite fertilizer. In: BOWMAN RS AND DELAP SE (Eds), Zeolite $2006-7^{\text {th }}$ International Conference on the Occurrence, Properties, and Utilization of Natural Zeolites, New Mexico, p. 114.

Goes AMd, Travassos WAS And Nunes KC. 1994. Projeto Parnaíba - Reavaliação da Bacia. In: CONGRESSo Brasileiro De GeOlogia 3: 311-311.

Jama B And Van StraAten P. 2006. Potential of East African Phosphate Rock Deposits in Integrated Nutrient 
Management Strategies. An Acad Bras Cienc 78: 781790 .

LeOnardos O, Theodoro SH And Assad ML. 2000. Remineralization for sustainable agriculture: A tropical perspective from a Brazilian viewpoint. Nutr Cycl Agroecosys 56: 3-9.

McDowell RW AND Sharpley AN. 2003. Phosphorus Solubility and Release Kinetics as a Function of Soil Test Concentration. Geoderma 112: 143-154.

McGechan MB AND Lewis DR. 2002. Sorption of Phosphorous by Soil - Part 1: Principles, Equations and Models. Biosyst Eng 82: 1-24.

Melfi AJ, Cerri CC, Fritsch E ANd Formoso MLL. 1999. Tropical soils: Genesis distribution and degradation of lateritic pedological systems. In: WORKSHOP ON Tropical Solls. Rio de Janeiro, Formoso MLL AND Cerri CC (Eds), p. 7-30.

Monte MBM, Duarte ACP, Bonapace JAP, Amaral MR JR, Vieyra A ANd SouzA-Barros F DE. 2003. Phosphate Immobilization by Oxide Precursors: Implications on Phosphate Availability before Life on Earth. Origin Life Evol Biosph 33: 37-52.

New Zealand Natural Zeolite. 2004. Data base of zeolitic organic fertilizer. Online:

http://www.zeolit.com.nz/organic_fertilizer.html.

PARK M AND KOMARNENI S. 1997. Occlusion of $\mathrm{KNO}_{3}$ and $\mathrm{NH}_{4} \mathrm{O}_{3}$ in Natural Zeolites. Zeolites 18: 171-175.

Pickering HW, MenZIES NW AND Hunter MN. 2002. Zeolite/Rock Phosphate - A Novel Slow Release Phosphorus Fertilizer for Potted Plant Production. Sci Hortic - Amsterdam 94: 333-343.
REZENDE NGAM AND ANGÉLICA RS. 1997. Geologia das Zeolitas Sedimentares no Brasil. In: PRINCIPAIS DEPÓSITOS Minerais Do BRASIL, Departamento de Produção Mineral, IV-B, p. 193-212.

REZENDE NGAM AND ANGÉLICA RS. 1999. Sedimentary zeolites in Brazil. Miner Petrog Acta 42: 71-82.

SteWART BA. 1975. Soil conditioners. In: SoIl SCIENCE Society of AMERICA - Special Publication, Madison, 7, p. 186.

van Olphen H. 1977. Clay Colloid Chemistry. J Wiley \& Sons, New York, p. 112: 137.

VAN StraAten P. 2006. Farming with rocks and minerals: challenges and opportunities. An Acad Bras Cienc 78: 731-747.

VAughan D. 1978. Properties of natural zeolites. In: Natural zeolites: occurrence, properties, use. SAND L AND Mumpton F (Eds), Pergamon Press, New York, p. 353372.

Wills BA. 1985. Mineral Processing Technology. Pergamon Press, Oxford, p. 421-455.

Young RA, SAKThIVEl A, Moss TS AND PAIVA-SANTOS CO. 1995. DBWS-9411 - An Upgrade of DBWS* Programs for Rietveld Refinement with PC and MainFrame Computers. J Appl Phys 28: 366-367. 